\title{
The Roots of Romantic Cognitivism: (Post) Kantian Intellectual Intuition and the Unity of Creation and Discovery
}

\author{
Christopher Macleod, Lancaster University
}

The final version of this paper appears in the European Romantic Review (2014) 25(4): 403-422.

\begin{abstract}
During the romantic period, various authors expressed the belief that through creativity, we can directly access truth. To modern ears, this claim sounds strange. In this paper, I attempt to render the position comprehensible, and to show how it came to seem plausible to the romantics. I begin by offering examples of this position as found in the work of the British romantics. Each thinks that the deepest knowledge can only be gained by an act of creativity. I suggest the belief should be seen in the context of the post-Kantian embrace of 'intellectual intuition'. Unresolved tensions in Kant's philosophy had encouraged a belief that creation and discovery were not distinct categories. The post-Kantians held that in certain cases of knowledge (for Fichte, knowledge of self and world; for Schelling, knowledge of the Absolute) the distinction between discovering a truth and creating that truth dissolves. In this context, the cognitive role assigned to acts of creativity is not without its own appeal.
\end{abstract}

During the romantic period, various authors expressed the belief that through creativity, we can directly access truth. This was not merely the claim that creative hypothesising is a necessary precursor to confirmation, or that the writer can create a world-in-fiction to which he comes to have exclusive epistemic access. Nor was it merely the claim that the human faculties are actively involved in moulding experience. This, to the romantic generation, was old news. The claim is a far stronger one: that via a productive and creative act, we can come to have direct access to truth that cannot be otherwise known. Call this position romantic cognitivism. ${ }^{1}$ The idea of knowing directly through an act of creativity has become foreign to us, and is a strange one. It is the purpose of this paper to try and cast light upon the roots of the theory.

It is worth emphasising at this stage that I do not attempt in this paper to convince the reader that romantic cognitivism is true. Neither do I give an historically detailed account of the origins and transmission of the position. ${ }^{2}$ Rather, I aim to render the position comprehensible and to present an account that will allow the reader to become sympathetic to the romantics' stance. Because it is short, the account given here will pass all too quickly over certain philosophic details, but will, I hope, convince the reader that romantic cognitivism is worth taking seriously. The claim that creativity can lead to truth is not a clumsy power-grab, made by poets seeking to privilege or legitimise their trade. It is a position with clear philosophic motivations.

I begin by highlighting that the thought that truth can be reached by creativity can be found in Coleridge, providing a short account of the position as it appears in his work. I go on to show that in endorsing romantic cognitivism, Coleridge is in good romantic company. A commitment to the position is also visible in the works of other contributors to what used 
to be termed the 'romantic canon': Wordsworth, Blake, Keats, and Shelley. This will come as no surprise to readers, the story having been well told previously by M.H. Abrams, amongst others. In what follows, however, I detail a part of the story that has not been so well told: how such a position could have come to seem plausible in the wake of problems internal to Kant's philosophy. All are aware that Kant's philosophic revolution provided the intellectual backdrop that facilitated an equally important revolution within literature; fewer, I think, will be clear on the nuts and bolts of this facilitation.

I consider how troubles within Kantian philosophy generated post-Kantian solutions that embraced romantic cognitivism. Kant had left unsolved the problem of how the human faculties could shape and render intelligible experience that was utterly foreign to the human mind, and how a unified self prior to that experience could be accounted for. He had developed the tools necessary for a resolution of these difficulties, however, in the form of a hypothetical faculty of intellectual intuition. The post-Kantian developed this notion of intellectual intuition, which merged the categories of creation and discovery. Creativity was given a central cognitive role, as a foundation for philosophy and a necessary precondition for the possibility of experience. ${ }^{3}$

\section{Romantic Cognitivism in British Romanticism}

Part of the romantic agenda broadly was to unify the notions of creation and discovery; this innovation grounds the account given by M.H. Abrams of the changing view of imagination in both The Mirror and the Lamp and Natural Supernaturalism. Abrams is not alone in highlighting the cognitive role that imagination plays for the romantics. Cecil Bowra's The Romantic Imagination is devoted to the thesis that the romantics "believed that the imagination stands in some essential relation to truth and reality" (5) and their claim "that poetry deals in some sense with truth" (7). This aspect of romanticism has recently been revisited by Charles Larmore, who writes that "the presumed antagonism between imagination and reality" formed the "struggle in which the Romantic project essentially consisted" (21). Their theory of the imagination, which he terms "Creative-Responsive", "is one that undoes the supposed dichotomies-between creative and responsive, expressive and mimetic, imagination and reality" that structure our own understanding of art's relation to the world (7-9).

The romantic attempt to sublate creation and discovery, as we shall see, takes the specific form of suggesting that through acts of creativity, we can directly uncover and reveal truths. Of course, not all romantic authors subscribe to the romantic cognitivist claim that the imagination can access truth in equal measure. A belief in the cognitive role of the imagination is not a stable article of faith, interpreted in the same manner by every thinker that endorses it; it is, rather, an open ended trope, with which the romantics often struggled, and to which they constantly returned. Neither was it a position explored purely philosophically. When articulated by the poets of British romanticism-it is these thinkers we shall consider first-it is not spoken in a philosophical voice. Even Coleridge's works, which come closest to engaging in purely philosophical enquiry, do not sustain the analytic rigour appropriate for philosophical texts. For the British romantic poets, the claim functions rhetorically, signalling a commitment to a belief in the power of the imagination, and it must be treated as such. Nevertheless, a commitment to the core thought that creativity has a cognitive role remains. And that the position is central enough to be contested and rearticulated in various authors makes it all the more clear how deeply the underlying claim influenced the romantics. It is this that must be explained. 
The epistemology Coleridge embraced-reaching beyond art in the narrow sense in to all areas of human enquiry - involves a merging of the categories of creation and discovery. Coleridge distinguishes the Reason and the Understanding. ${ }^{4}$ The Understanding is the procedural or discursive rational faculty: it reasons inductively and deductively, by means of reflection, generalisation, and abstraction. Reason is the faculty of Ideas, which are super-empirical, almost Platonic, objects of thought.

I should have no objection to define Reason ... as an organ bearing the same relation to spiritual objects, the Universal, the Eternal, and the Necessary, as the eye bears to material and contingent phaenomena. (Coleridge The Friend 4[1]: 155-6)

Unlike the Understanding, the Reason is generative. It is an "irradiative Power", which creates, synthesises, and produces (Opus Maximum 15: 87). "Reason in all its decisions appeals to itself, as the ground and substance of their truth" (The Friend 4[1]: 155-6). Reason is productive, provides its own materials, and in this sense Coleridge indicates that it is a genuinely creative faculty - a faculty involved in originating ideas rather than reflecting externalities— that reaches truth by its autonomous activity. The poles of creation and discovery are thereby moved closer together. Indeed, as Mary Perkins points out, "Reason includes the faculty of Imagination" (404). Coleridge himself notes that it is "wonderful, how closely Reason and Imagination are connected" (The Friend 4[1]: 203n).

Coleridge distinguishes two aspects of Imagination — the primary and secondary—but first of all separates the active operation of the Imagination entirely from the mechanical operation of the Fancy. The Fancy, being merely "Memory emancipated", operates by reordering past perceptions, but is not productive, and does not relate to Truth (Biographia Literaria 7[1]: 305). In contrast, the Imagination does not merely reorganise, but creates. The primary Imagination is the central philosophic organ of all mental activity: "The primary IMAGINATION I hold to be the living Power and prime Agent of all human Perception" (Biographia Literaria 7[1]: 304). As such, Coleridge extends creativity a role in all acts of belief-formation. This primordial act of production, which is the enabling condition of all access to Truth, is, for Coleridge, present in all acts of what we commonly call 'artistic' creativity, which are acts of the secondary Imagination. In such acts, the Imagination is again active in simultaneously creating and discovering. "The secondary Imagination I consider as an echo of the former, co-existing with the conscious will, yet still as identical with the primary in the kind of its agency, and differing only in degree, and in the mode of its operation" (Biographia Literaria 7[1]: 304). All acts of Imagination have this cognitive feature, forging a direct connection with Truth.

Imagination is, for Coleridge, an activity of self that is ultimately identical to selfhood: it is "a repetition in the finite mind of the eternal act of creation in the infinite I AM" (Biographia Literaria 7[1]: 304). The importance of this claim will become clear in the following sections, when apperception will emerge as pivotal in the post-Kantian account of creative-discovery. For now it will suffice to note that Coleridge holds that only the Imagination, in both its primary and secondary form, is capable of direct cognitive contact with Truth, because nature is itself vital and living: natura naturans, a constant act of becoming takes central place in the metaphysics. "Remember that whatever is, lives" (Church and State 10: 183). Because the world is dynamic and creative rather than mechanical, so the individual's engagement with truth must be, too.

Though it is articulated in quite a different way, Wordsworth shares the belief that, in the creative or imaginative act, truth can be discovered. The Prelude is described by Wordsworth as 
a history "Of intellectual power, from stage to stage / Advancing, hand in hand with love and joy, / And of imagination teaching truth" (207; bk. 11: 43-5). It is the imagination that

lifts

The Being into magnanimity;

Holds up before the mind, intoxicate

With present objects and the busy dance

Of things that pass away, a temperate shew

Of objects that endure[.] (Prelude 219; bk. 12: 31-3)

For Wordsworth, as for Coleridge, the creative faculty is endowed with an ability to uncover truth. And, again, as such, this creative faculty is linked to the cognising faculty of Reason. Wordsworth writes that imagination is

but another name for absolute strength

And clearest insight, amplitude of mind,

And Reason in her most exalted mood. (Prelude 233; bk. 14: 190-2)

Such a conception of Reason is distinguished from the mere discursive understanding, or the "self-applauding intellect", in Wordsworth's terms (Prelude 233; bk. 14: 190). Without the exercise of imagination, the use of the mere understanding leaves "Caverns ... within my mind, which sun / Could never penetrate" (Prelude 41; bk. 3: 245-6). ${ }^{5}$ Acts of genuine creativity can fulfil an intellectual and not mere expressive role-and the disclosing role of imagination renders poetry a vehicle for arriving at truth.

Poetry is the most philosophical of all writings ... its object is truth, not individual and local, but general, and operative; not standing upon external testimony, but carried alive into the heart by passion. (Wordsworth Lyrical Ballads 301)

Wordsworth and Coleridge are the prime exemplars of the romantic impulse to unite creativity and discovery. Independently, however, Blake articulates a strikingly similar view on the role of creativity in accessing truth. As one would expect, there are subtle differences to the details of Blake's view. Both Coleridge and Wordsworth's romantic cognitivism have theological dimensions, being connected to pantheistic modes of viewing the relation of man, world and God-yet their consideration of the intersection of creativity and discovery takes place on the terrain of philosophical theology. Blake's spiritual enthusiasm leads him to articulate the unity of creation and discovery in richer language, less philosophical but more appropriate to the development of a renewed Christian mythology. The confidence Blake places in the creative imagination as a route to truth often turns on imagination itself being a reflection of God. ${ }^{6}$ Blake holds that the imagination- "The Divine Vision" — has a direct cognitive function, and assigns free creativity the role of revelation (On Wordsworth 665). "Vision or Imagination is a Representation of what Eternally Exists, Really Unchangeably" ( $A$ Vision of the Last Judgment 554). "I am Inspired! I know it is Truth! For I sing / According to the inspiration of the Poetic Genius" (Milton 108). Contrasted, the non-imaginative cognitive process is held to be mere "Two Horn'd Reasoning, Cloven Fiction, / In Doubt, which is Self contradiction" (Gates of 
Paradise 268). For Blake, as, Northrop Frye notes, "a man's imagination is his life. 'Mental' and 'intellectual' ... are exact synonyms of 'imaginative" " (19).

Keats, too, takes on the position, but is not in the end as wholehearted in his support as Blake, Wordsworth or Coleridge. ${ }^{7}$ In letters, Keats claims to be "certain of nothing but of the holiness of the Heart's affections and the truth of Imagination-What the imagination seizes as Beauty must be truth" (365), and feels comfortable speaking of his progress as "a regular stepping of the Imagination towards a Truth" (376). But if these seem to be unabashed declarations of romantic cognitivism, he retains at other moments an underlying suspicion that this account of the power of the imagination is too good to be true. The comparison of imagination "to Adam's dream,- - he awoke and found it truth" (365) is double-edged and, on pain of making the imaginative faculty seem magical, Keats implies that the imagination, like a dream, has a perspective-altering function, allowing one to find truth simply by colouring one's interpretation of the world. The equation of Truth and Beauty in Grecian Urn is not without irony, being merely "all / Ye know on earth, and all ye need to know" (289), and Keats quickly shakes the reader out of the imaginative flight of Ode to a Nightingale with the reminder that such a flight is not reality: "the fancy cannot cheat so well / As she is fam'd to do, deceiving elf" (288). ${ }^{8}$

Whether Keats in the end reaches any settled judgment on the romantic cognitivist claim, a struggle with the relation of imagination and truth is pervasive in his work. So too, a version of the thesis is appealing to Shelley, even if he sometimes falls back on the claim that creativity merely expresses truth given by a natural world far more powerful than the human imagination. When, for instance, Shelley offers a Defence of Poetry, the battle is fought on many fronts, but imagination's role of discovering significant truths is made central. Shelley prefers the vocabulary of 'poetry', to that of 'imagination', but despite this variation, the theme is familiar. Poets are referred to as prophets, who "apprehend the true and the beautiful" (112). Poetry "enlarges the mind" (117). It is "the very image of life expressed in its eternal truth" (115). The "creative faculty, which is the basis of all knowledge" is given responsibility for "the invention of the grosser sciences, and that application of analytical reasoning to the aberrations of society" (134). Poetry is "the centre and circumference of knowledge" (135).

Indeed, of those contributors to the traditional 'British romantic canon', it is only Byron that does not offer an extended theoretical treatment of the power of the imagination, and it is only he that does not elevate the imagination to a cognitive role. ${ }^{9}$ Nor is romantic cognitivism visible only in thinkers central to the canon, narrowly conceived. More examples could be given of the influence of this general line of thought in thinkers normally considered to operate at the fringes of romanticism. ${ }^{10}$

To isolate this commonality in various romantic thinkers is not, I repeat, to claim that the philosophic position of each is identical, or that romantic cognitivism is held with equal assurance by each author we might find it useful to label 'romantic'. Nor is it to essentialise one aspect of romanticism: if anything has become clear about the period in recent years, it is surely the many ways in which the romantics and their contemporaries were far from monolithic, each having problems, agendas, and ideals of their own. Romanticism is not a 'natural kind term', and expecting deep commonalities between a disparate group of authors will not get us far. ${ }^{11}$ Yet I hope that enough has been said to justify the claim that a form of romantic cognitivism was common currency during this period.

I wish now to consider how this position might have come to be seen as philosophically tenable. As we shall see, the claim that we can make direct cognitive contact with truth by acts of creativity can be seen as a solution to problems internal to Kant's philosophy. We should, 
of course, exercise moderation in claiming that one and the same idea is at work in the writings of the British romantics and philosophers reacting to Kant. A criterion of identity for ideas articulated by thinkers operating in different contexts is difficult to establish, even within tighter time periods than the one under consideration, and the truths the German Idealists sought to establish as amenable to creative-discovery were quite different from those of the British romantics- their thought being concerned with social, moral, and aesthetic questions, rather than those concerning the foundations of knowledge. The historical task of tracing connections and transformations of the idea must be left to another occasion. Given how foreign the central claim of romantic cognitivism has become to us, it is the persistence and credibility of the idea in the period that I here wish to investigate.

\section{Intellectual Intuition and Creativity in Kant}

The opening move of the Transcendental Aesthetic of the Critique of Pure Reason is to distinguish intuition and concept.

In whatever way and through whatever means a cognition may relate to objects, that through which it relates immediately to them, and at which all thought as a means is directed as an end, is intuition. (CPR A19/B33) ${ }^{12}$

Objects are "given to us by means of sensibility, and it alone affords us intuitions; but they are thought through the understanding, and from it arise concepts" (CPR A19/B33). Intuitions are the vehicle through which objects are directly presented to us; concepts allow us to make judgments about those objects.

Looked at from a sufficient level of generality, this is really all that can be said about the distinction. At this stage, Kant has presented us with a purely formal characterisation of the conditions for cognition in general. As cognition occurs for the human subject, Kant fleshes the account out substantially throughout the Doctrine of Elements. A useful summary is given in the early stages of the Transcendental Logic.

Our cognition arises from two fundamental sources in the mind, the first of which is the reception of representations (the receptivity of impressions), the second the faculty for cognising an object by means of these representations (spontaneity of concepts); through the former an object is given to us, through the latter it is thought in relation to that representation (as a mere determination of the mind). Intuition and concepts therefore constitute the elements of all our cognition, so that neither concepts without intuition corresponding to them in some way nor intuition without concepts can yield a cognition. (CPR A50/B74)

We might think of intuition as the raw sense data presented to consciousness. We are receptive to such intuitions, passively related to them. Concepts, by contrast, are those structuring and comparative features that we actively employ in thinking about that data. We apply concepts spontaneously to intuitions to make them comprehensible. Both intuitions and concepts are necessary for us in cognition of objects, and as Kant puts it, "[t]houghts without content are empty, intuitions without concepts are blind” (CPR A51/B75).

It is important, however, to note that these are substantive commitments on how human beings perceive objects. There is no reason to think that this mode of apprehension is the only 
one that is logically possible: other beings might very well be constituted such as to perceive in an entirely different manner. Thus Kant writes:

It is also not necessary for us to limit the kind of intuition in space and time to the sensibility of human beings; it may well be that all finite thinking beings must necessarily agree with human beings in this regard (though we cannot decide this), yet even given such universal validity this kind of intuition would not cease to be sensibility, for the very reason that it is derived (intuitus derivatives), not original (intuitius originarius), thus not intellectual intuition[.] (CPR B72)

Though we perceive according to sensible intuition, not all beings need do so, and Kant terms one such alternative intuitive faculty 'intellectual'. ${ }^{13}$

A being with intellectual intuition would perceive directly and non-derivatively: it would be a being for which there would be no need for the bringing of intuitions under concepts (the intuitions achieved would in this case be in the literal sense "immediately" represented (Kant What Real Progress has Metaphysics Made 20: 267).) A being with this hypothesised manner of perceiving "does not intuit objects according to conditions of sensibility, and does it by way of the understanding" (Kant What Real Progress has Metaphysics Made 267). And in such a case, the understanding would be "operat[ing] like the senses, having pure intuitions" (Kant LM 29: 954). A being with intellectual intuition would be "free, in his knowledge, from all sensibility, and at the same time from the need to know by concepts" (Kant What Real Progress has Metaphysics Made 20: 267).

Under the possession of intellectual intuition, Kant notes, there exists no distinction between sensible intuition and concept. "[B]oth disappear" for an intuitive understanding (CPrR 5: 402). Indeed the distinction between intuition simpliciter and concept seems redundant, given that the role of concept has in effect been integrated into intellectual intuition (Gardner 69). Just as the barrier between intuition and concept has been dissolved, so too the divide between passivity and activity is undermined. The understanding being now an autonomous faculty of perception, intellectual intuition is "mere self-activity" (CPR B68). Providing both the matter and form for perceptions, an agent with intellectual intuition is receptive to nothing but its own "complete spontaneity of intuition" (CJ 5: 406).

The implications of this are important to our understanding of the development of romantic cognitivism, because the distinctions that would be undermined for a being in possession of intellectual intuition are those that ground the barrier between creation and discovery. The primary distinction between creatively summoning an object to one's mind and perceiving an object in the world, of course, is that while the former is free, the latter is constrained by how the world is. For the ordinary agent, that is to say, while we may be free to imagine as we like, perception remains at least partially determined by external content, which is an independent variable beyond one's control. But for an agent who is entirely active in all cognition, there would be no distinction between constrained discovery and free productivity. As Hanna observes, for such a being, "to think it, is to make it so; to conceptualise an object is thereby to intuit that very object" (198).

As A.B. Dickerson writes, an agent in possession of intellectual intuition is "not receiving data from an independent reality, but rather creating the data and thus creating that reality" (161). An agent who was totally spontaneous in their intellectual life-to the extent that perceiving an object is no more than providing one's self with the data of perception by an act of 
thought—-would no longer be at the behest of some world external to mind. Rather, 'perception' for such a being, would be a free act of creativity. One who posseses intellectual intuition, as Freydberg notes, "creates its object in the very act of knowing it" (30).

For a being for whom thinking of an object and being presented with that object are one and the same act, discovery and creation are ultimately identical. The mind's act of entertaining the thought of an object would be identical to its bringing the object into existence. And as such cognition would be the only mechanism of thought for a being without the distinction of intuition and concept, there could be no act of thought which did not furnish its own intuition and thereby bring about its object. Such is the consequence of supposing an intellect could perceive with pure spontaneity, and there is no question that Kant sees this consequence. "[I]ntellecual intuition would grasp and present the object immediately, and all at once" (On a Recently Prominent Tone 8: 390). "If our understanding were intuitive, it would have no objects except what is actual" (CJ 5: 402). "[A]ll objects that I cognise would be (exist)" (CJ 5:403). "If we had intellectual intuitions, then our understanding would have to be creative and produce the things themselves" (LM 29: 881).

Kant, as was noted above, does not think that humans have intellectual intuition. "There can be such an understanding, but the human understanding is not it" (LM 29: 241). (We might well pause to consider that his choice of word for the false doctrine that we do intuit intellectually—one that the romantics would come back to again and again—was "mysticism".) A plausible candidate for possessing the faculty, he however speculates, is God. ${ }^{14}$ And indeed, as a manner of articulating the sort of perception that Kant is attempting to elucidate, this is a helpful model. In considering what a divine intellect might look like, we are forced to consider whether the distinctions of creativity and discovery, spontaneity and receptivity, can be sustained where concept and intuition are merged. If God apprehends the world directly, there is no distinction between his thinking something and it being so. Höffe compares Psalm 33 v. 9- "for he spake, and it was"- "a divine reason could creatively 'see' anything into existence through the agency of an intuitus origanarius or intellectual intuition" (88-89). ${ }^{15}$

\section{Post-Kantian Worries: Interaction, Pure Concepts, and Ap- perception}

If the notion of intellectual intuition played a relatively minor role in Kant's philosophy, it would come to be a dominant theme amongst the post-Kantian Idealists. It is through this dominance of the notion that the idea of creative-discovery became philosophically credible, and it is an appreciation of the arguments that were advanced by the post-Kantians in favour of humans possessing intellectual intuition that renders romantic cognitivism intelligible.

Of all Kant's positions, the distinction that was drawn between concept and object was held to be one of the most problematic. In Beiser's words, Kant

insisted upon a dualism between understanding and sensibility, so that the transcendental subject is the source of only the form but not the matter of experience. It was then the task of Kant's great successors ... to remove these recidivistic inconsistencies and to complete Kant's revolution. (2)

The post-Kantians possess a drive to transcend dichotomies wherever present, and this division in the mind "seemed schizophrenic in that it split human life into two or three irreconcilable 
sections without indicating how these should be brought together" (Solomon 45). The dualism was a philosophic invitation, and their appetite had been whet by Kant's claim that "there are two stems of human cognition, which may perhaps arise from a common but to us unknown root" (CPR A15/B29). Fichte and Schelling, as we shall see in the following sections, make it their goal to overcome Kant's dualism and give an account of the 'common root'.

At least three substantive arguments against Kant's claim that sensibility and understanding-intuition and concept-are distinct emerge from the context of post-Kantian Idealism, however, and it is worth considering these arguments first. The first such argument comes from Maimon. Maimon suggests that Kant's division of sensibility and understanding renders the act of perception dependent on an impossible interaction of two entirely heterogeneous faculties. Understanding has to act on intuition to order content, and Kant is yet to explain how this could be possible.

[Q]uid juris? ... How can something a priori apply with certainty to something a posteriori? In this case the answer or deduction that [Kant] give[s] us is completely satisfying ... But if the scope of the question is enlarged, it demands: How can an a priori concept apply to an intuition[,] even to an a priori intuition? (Maimaon 229)

Maimon thinks that the question is unanswerable, so long as sensibility and understanding are cognitively distinct. The mind-body dichotomy had been the undoing of the Cartesian approach, and now the concept-intuition dichotomy provided a new problem of interaction. This worry was good ammunition for the post-Kantians, who sought to fuse the faculties. The charge, however, was not confined to the claim that Kant should have acknowledged the unity of sensibility and understanding. The post-Kantians also claimed that Kant had already unknowingly committed to a mixing of the notion of concept and intuition and the unification of the faculties.

The goal of explaining how objects of perception are possible for us can only be realised, Kant suggests, if there can be said to be pure concepts of the understanding, prior to all experience. We operate with a range of empirical concepts, but these can neither account for the ability to unite the sensory manifold into objects for the abstraction and formation of such concepts, nor can they account for the determination of which empirical concepts can be well-formed. In order to unify the sensory manifold (the content of experience), we must be constrained by some fundamental laws of synthesis. For Kant, the question as Pippin puts it is, "what accounts for the normative limitations on collecting together and uniting that constitutes representing?" (Hegel's Idealism 26)

The answer Kant provides is that it is the concepts of Quantity, Quality, Relation, and Modality, which are given a priori by the understanding, that provide both de facto and normative rules for how we unite the manifold. Kant's argument leading to this conclusion-the deduction of the table of categories in the Transcendental Analytic-is taken to be one of the most difficult sections of the first Critique. We need not examine the argument in detail in order to see why the post-Kantians found the general strategy troubling, however. To the extent that there was an attempt to limit given content by means that were both objective and subjective, whether by mediating judgments or imagination, or "determining [of] sensibility internally" (CPR B153), there was an amalgamation of intuition and concept.

Now all experience does indeed contain, in addition to the intuition of the senses 
through which something is given, a concept of an object as being thereby given, that is to say, as appearing. (CPR A93/B126)

But if conceptual form was something given or appearing in intuition, rather than applied to intuition - and this seems to be Kant's method of showing that the "subjective conditions of thinking ... have objective validity" (CPR A89/B122) — then there seemed to be a blending of understanding and sensibility. Pippin, once again, describes their problem well:

He appears to be trying to argue that objects "in their very givenness" conform to the categories. But if he is successful in doing this, then he has shown that what counts as given in experience is also determined by conceptual conditions, by the "spontaneity" of the subject. And this would render problematic the whole distinction between spontaneity and receptivity ... identity between Concept and intuited Particular looms on the horizon. (Hegel's Idealism 29-30)

The problems of the Transcendental Deduction, and its apparent mixing of concept and intuition, were major themes in the work of Kant's successors, including Fichte and Schelling. Particularly central to their interest, however, was a specific claim made during the derivation of the Categories about the nature of the 'I'. Kant follows Hume in finding no presentation of the self within experience (Hume 164-5). At an empirical level, there neither is, nor could be, any perception of a metaphysical self.

The consciousness of oneself in accordance with the determinations of our state in internal perceptions is merely empirical, or ever variable; it can provide no standing or abiding self in this stream of inner appearances[.] (CPR A106)

Though the self, according to Kant, is not present in the manifold of intuition, an awareness of these perceptions as unified must accompany representations in order for them to qualify as perceptions at all.

$[\mathrm{N}]$ o cognitions can occur in us, no connection and unity among them, without that unity of consciousness that precedes all data of the intuitions, and in relation to which all representation of objects is alone possible. This pure, original, unchanging consciousness I will now name transcendental apperception. (CPR A107)

Kant terms this transcendental apperception because the unchanging consciousness to which he refers is a consciousness of the ' $I$ '. The purely formal unity that is to bind representations together, Kant claims, can be only the mere consciousness of representations as mine. As such, "[i]t must be possible for 'I think' to accompany all my representations". (CPR B131) If representations are to belong together as representations to a self, they must be perceived as belonging. Mere belonging, that is to say, is not enough: the "unity of consciousness would be impossible if in the cognition of the manifold the mind could not become conscious of the identity of the function by means of which this manifold is synthetically combined into one cognition." (CPR A108)

Kant argues that in order for there to be experience, as such, we must be able to conceive of the experience as belonging to an experiencing self. The post-Kantians felt unsatisfied: Kant 
had shown that "the 'I think' must accompany all my representations", that in some manner experience is apperceptive, but not how such a condition could pertain (Pippin Hegel's Idealism 43). The question of how the thinking I was present in all experience remained open.

Again, the dualisms between receptivity/spontaneity and sensibility/understanding seemed to crumble under the transcendental microscope. We are not presented with the 'I think' through the sensibility, yet neither do we apperceive conceptually. Kant tells us that apperception is an "act of [the subject's] self-activity" (CPR B130), and it is an activity of the understanding, yet it is unclear how the self could be presented in this manner, rather than merely arbitrarily 'read into' the manifold. Kant's commitment to an act of apperception, which was in this sense self-validating, relied on the self being somehow found and posited in the same act of apperception, and this seemed to blur the distinction between spontaneity and receptivity.

What Kant in an earlier work called a "mysterious power" (False Subtlety of Four Syllogistic Figures 2:60) had become in the first Critique "the supreme principle in the whole sphere of human cognition" (CPR B135). Yet it remained, in the view of the post-Kantians, mysterious. Though it fit the profile of what might be considered an intellectual intuition — an apparently contentful yet non-sensible perception delivered and created by the understanding-Kant denied that this was what the act of apperception amounted to (CPR B159). Yet the claim that apperception was merely "an analytical proposition" (CPR B135) did not seem convincing.

\section{Fichte: Creative-Discovery of Self and World}

Fichte's claim that the self posits itself and world is, from the outside, obscure. Yet, it is in understanding his claim that we see how romantic cognitivism also might come to seem defensible. Within the post-Kantian context which the work appears, there were two important strands: the first was the worry, already outlined, about the division of intuition and concept, sensibility and understanding, and passivity and spontaneity. The second was the ongoing attempt to offer a foundationalist account of transcendental idealism along the model of K.L. Reinhold.

Reinhold's worries, shared by many, about the foundations of Kant's work-primarily the lack of systematicity in establishing theoretical foundations as given in the deduction of the categories - had led him to attempt, in the Elementarphilosophie, a statement of transcendental idealism along foundationalist lines. The attempted mending of the Kantian system depended on derivation from the base Reinhold termed a "proposition of conciousness" (Beiser 247). The details of this derivation need not concern us here. G.L. Schulze, in response to Reinhold, published the dialogue 'Aenesideum' attacking this restatement of the critical philosophy, claiming that it resulted in the scepticism that Kantianism aimed to avoid. This debate had led to the entrenchment of the aim producing a foundationalist statement of transcendental idealism. Fichte adopted this as his goal, which as Ludwig Siep observes, is an ambitious one.

Regarding this demand for certainty, Fichte's standards are even higher than Kant's, as he couples the transcendental method with the demands of Rationalism since Descartes and Spinoza, i.e., that all knowledge must be founded in a single, supreme, self-grounded and indubitably evident principle. (59)

Fichte takes Kant to have shown that the doctrine of apperception is the supreme principle of epistemology (W 1.475). ${ }^{16}$ Kant had shown that consciousness was determined by the condition of self-consciousness, and in this sense "a system of philosophy", Fichte claims, "would have 
to set out from the pure self" (W 1.477). The Wissenschaftslehre does exactly that, starting the project of justifying human knowledge with the claim that "[t]he self posits itself, and by virtue of this mere self-assertion it exists; and conversely, the self exists and posits its own existence by virtue of merely existing" (W 1.96). Fichte takes this starting point to be indubitable by a free being. Insofar as we are unconditioned and autonomous, the self must give itself its own form. "The self presents itself to itself, to that extent imposes on itself the form of a presentation, and is now for the first time a something" (W 1.97).

Self-postulation is prior to any possession of concepts or sensible intuitions, the existence of a self-consciousness being itself a precondition for any sort of knowledge. The act "comprises only the form of selfhood, the self-reverting act which also, in fact, itself becomes the content thereof" (W 1.515). Because the self that is found in this postulation is both form and content, it is described as both concept and intuition (W 1.516). We have seen that, for Kant, where the distinction between concepts and sensible intuition ceases to apply, we are in possession of intellectual intuition, and the distinction between perceiving something to be the case and making it the case dissolves. Contrary to what Kant had maintained, Fichte holds exactly that the "primordial" (W 1.91) act of apperception is an act of intellectual intuition. ${ }^{17}$ "This intuiting of himself that is required of the philosopher, in performing the act whereby the self arises for him, I refer to as intellectual intuition" (W 1.463).

The positing of ourselves, that is to say, is merely having an intellectual intuition of our own existence. Our existing is identical to our positing of our existence, and we discover ourselves in the act of self-positing. The individual is a "self-constructing self": "freely, and by his own choice, he brings it about in himself" (W 1.459). "It is so, because I make it so" (W 1.460). "To posit oneself and to be are, as applied to the self, perfectly identical" (W 1.99).

Fichte makes it clear, further, that self positing is an act. We should not be mistaken into thinking that we bring ourselves into existence by self-positing: rather, self-positing constitutes the existence and discovery of the self. The self should not be conceived of as a 'res': its existence as act exhausts its being (Siep 59). It is the activity of self-positing, that is to say, and not its result, that is identical with the self and apperceptive awareness of the self. "The intellect, for idealism, is an act, and absolutely nothing more; we should not even call it an active something" (W 1.440). "The intellectual intuition alluded to in the Science of Knowledge refers, not to existence at all, but rather to action" (W 1.472). We do not discover what is created, rather discovery and creation are in this instance one and the same. As Pinkard puts it, we are "instituted, and not, as it were discovered", and this instituting is normative, and self-authorising (113-4). For this reason, Fichte describes self postulation as a 'deed-act' (tathandlung), and emphasises the importance of the distinction between this foundationalism and Reinhold's, which was based on a perceived fact (W 1.468).

Fichte has, by this point, accounted for the self and self-presentation. Given the foundationalist aspirations of the Wissenschaftslehre, his next project is to account for the presentation of the not-self from this self. And, Fichte claims, the not-self is to be explained by the same activity that gives rise to the self. A "not-self is opposed absolutely to the self" (W 1.104); "[t]he self posits absolutely an object (a contrasted, counterposited not-self)" (W 1.258). The activity of the self is held to be responsible not only for the presentation of itself, but also for the presentation of the world.

Insofar as it can be considered as related to us, then, the not-self exists as posited. No other foundation can be given to it: " $t$ ] he source of all reality is the self, for this is what is immediately and absolutely posited" (W 1.134). This is a condition of our having knowledge about the not- 
self, and Fichte explains such interaction in terms of the "limit" that not-self applies to self. "Both self and not-self are posited, in and through the self, as capable of mutually limiting one another" (W 1.125). This is again pre-conceptual, and is how empirical perceptions and experience of the world arise: "presentation consists in the fact that the self posits a subjective and counterposits another thing thereto as an objective, and so on" (W 1.209). The 'so on' here clearly has much to do: by the process of dialectical positing and counterpositing, Fichte means to derive the categories of judgment and subjective content of experience. But Fichte's result is "therefore that all reality_for us being understood, as it cannot be otherwise understood in a system of transcendental philosophy—is brought forth solely by the imagination" (W 1.227).

For Fichte, then, a creative act, positing, is the path to knowledge of both self and world. ${ }^{18}$ Possessing an ability for intellectual intuition-knowing unconditioned by the distinction of concept and object-the division for human beings between truth-tracking and truth-making is, Fichte suggests, more fluid than we might be accustomed to think. As we shall now see, Fichte was not the only thinker in this tradition to reach this conclusion.

\section{Schelling: Absolute and Art}

Schelling's early work follows Fichte in attempting to provide a systematic statement of transcendental idealism, and in taking the activity of apperception to provide the foundation of such a system. Self-consciousness, once again, is to be the "Supreme Principle of Knowledge" (STI 15). ${ }^{19}$ And, as for Fichte, such self-consciousness must be seen as act, identical to the self, in the form of an intellectual intuition that is at once a production and perception of the self.

In contrast to sensory intuition, which does not appear as a producing of its object and where the intuiting itself is therefore distinct from the intuited, an intuition [that is simultaneously a producing of its object] will be called intellectual intuition. The self is such an intuition, since it is through the self's own knowledge of itself that that very self (the object) first comes into being. For since the self (as object) is nothing else but the very knowledge of itself, it arises simply out of the fact that it knows of itself; the self itself is thus a knowing that simultaneously produces itself (as object). (STI 27)

The centrality of intellectual intuition is once again founded on its priority to the possible acquisition of conceptual apparatus. In intellectual intuition, "subject and object are immediately one" (STI 24), and in this context the form and content of the judgment "reciprocally condition" each other. (STI 21) Intellectual intuition is immediate- "absolutely unmediated" (STI 55) - and "hence it can never fall into the domain of demonstrable concepts" (Schelling 'Of the I', qtd. in Pinkard 176). Consequently, concept and intuition "can and should never be separated" (IPN 173), and in knowledge generated by intellectual intuition, "intuition and concept, form and object, ideal and real, are originally one and the same." (IPN 35) The collapse of concept and object once again results in a seeping of creativity into discovery. As Pinkard puts it,

spontaneity had to be somehow at one with receptivity in human knowledge; to be led to the point where conceptual argument is of no more value, Schelling concluded, is to be led 'into a region where I do not find firm ground, but must produce it myself in order to stand firm upon it.' (176-7) 
Intellectual Intuition, then, is again placed at the centre of philosophy: "Without intellectual intuition no philosophy!" (Schelling Vorlesungen, qtd. in Beiser 580). And Intuition is again "productive" in positing matter and nature (STI 72). We should not see nature as prod$u c t$, however; this is to alienate a world that we must have access to. The separation of active idea and passive object is "spiritual sickness", a product of an incomplete philosophy of "mere reflection" on objects (IPN 11). If we are to have successful cognitive contact with objects, "a point must surely come where mind and matter are one" (IPN 40). Nature is seen, then, as a productivity that can only be reflected on as product.

The distinctive contribution of Schelling's early work for our purposes comes from this fuller explication of the pre-conceptuality condition on intellectual intuition: the nature of the product of the intellectual intuition, and the project of providing such an account. The intellectually intuited, Schelling refers to as 'the Absolute'. The Absolute is, as unmediated by concepts, a totality: limitation comes about through acts of predication; to apply concepts, we disjoin an object from what it is not, and thereby bound it. But the intellectually intuited is not encountered in this manner: our access to it is immediate, and therefore it alone is pure unity. The Absolute "cannot, in fact, have any predicates whatever; for it is the absolutely simple, and thus can have no predicates drawn either from intelligence or free agency." (STI 209) Indeed, the intuited cannot even be rightly thought of even as object or subject, transcending even these categories. The Absolute, rather, is merely self-reflective Being, and as such, Schelling prefers to refer to the Absolute as 'subject-object'.

The pre-conceptuality and subject-object identity of the Absolute is used by Schelling to reclarify the notion of intellectual intuition that had been present in the work of Kant and Fichte. Schelling defines intellectual as "the capacity to see the universal in the particular, the infinite in the finite, and indeed to unite both in a living unity" (Schelling Vorlesungen, qtd. in Beiser 580). Concepts apply to an infinite plurality, and object a concrete singularity: intellectual intuition is not bound by this distinction, and sees these two in their primordial unity and co-dependence. Outside the domain of concepts and objects, there is nothing that it means to be universal or particular. As Beiser writes: "what I intuit is the identity of the universal and particular; I see how the particular is inseparable from the whole of which it is a part, and how the whole cannot be without that particular" (581). This merging of all into unity collapses the subject and object distinction also: there is no categorical discontinuity between subject and object, both being a manifestation of the Absolute.

This reclarification of intellectual intuition, however, leads to a notable difficulty, which we might term the problem of articulation. Given that intellectual intuition of the Absolute is preconceptual and immediate, how can we give any expression to it when our means are entirely conditioned? As Bowie poses the difficulty: "how can one say anything about what must have been before anything could be said?" (99) If the Absolute defies characterisation by concepts, then how can it be articulated and put to use at all?

Schelling addresses the problem of articulation-the problem of how to articulate the very foundations of philosophy-head on. We cannot demonstrate or speak about the Absolute: as Horstmann puts it, it cannot be given "as an object; it is the pre-objective identity of spirit with itself" (134). But we can nevertheless be made aware and manifest it via artwork. "Schelling makes art into the organon and criterion of intellectual intuition ... he maintains that aesthetic experience is the medium and proof of our awareness of the absolute" (Beiser 584).

The whole of philosophy starts, and must start from a principle which, qua abso- 
lutely identical, is utterly non-objective. ... That it can no more be apprehended through concepts than it is capable of being set forth by means of them, stands in no need of proof. ... This universally acknowledged and altogether incontestable objectivity of intellectual intuition is art itself. (IPN 289)

"[A] esthetic intuition is precisely intellectual intuition which has become objective" (IPN 229). In this sense, art is "the only true and eternal organ and document of philosophy, which always and continuously documents what philosophy cannot represent externally" (IPN 231).

Schelling nominates the aesthetic because the characteristics we have seen are merged in the absolute-its status as subject-object and being universal-in-particular-make artwork the appropriate vehicle for an indirect sort of representation of the Absolute. The artwork manifests both the objective and the subjective; as Beiser puts it, "the subjective pole of the absolute manifests itself in free and conscious activity, and ... its objective pole appears as necessary and subconscious activity" (Beiser 584). Art brings together "on the one side the product of nature, and on the other upon the product of freedom ... unit[ing] in itself the characteristics of both" (IPN 219). "The work of art reflects to us the identity of the conscious and unconscious activities" (IPN 225), and in so doing parallels the object-subject identity of the Absolute. The artwork is, additionally, universality displayed in particularity. Artworks are necessarily open to a multitude of interpretations, and thereby present the infinite possibility in the finite. "So it is with every true work of art, in that every one of them is capable of being expounded ad infinitum, as though it contained an infinity of purposes" (IPN 230). Thus, generality of concept and particularity of object are transcended in the artwork. In Bowie's terms, "the meaning of the work cannot be exhausted, even though it is manifested in an object" (52).

Art, then, is a manifestation of the Absolute-it expresses what cannot properly be articulated. And, yet, it would clearly be a mistake to think that art allows us somehow to metaphorically depict some separate 'Absolute' already encountered. "[T] he real world evolves entirely from the same original opposition as must also give rise to the world of art" (IPN 231). "[W] hat we speak of as the poetic gift is merely productive intuition, reiterated to its highest power. It is one and the same capacity that is active in both ... its name is imagination" (IPN 230). Rather, art is our only access to the Absolute, from the inside, for productivity of self is what drives the Absolute. Intellectual intuition, that act in which we creatively-discover the Absolute, is best displayed by the medium of creativity, for it is creativity. Again, then, the emphasis is not on the communication of truth already apprehended, but on the cognitive function that creativity itself performs.

\section{Conclusion}

As stated above, it has not been my purpose in this paper to try and persuade the reader that romantic cognitivism is correct. Nor has it been my purpose to track romantic cognitivism's migration from German philosophy to the British literature, though causal lines of influence do certainly exist, and an historical story can be told about Coleridge's reproduction and dissemination of the work of Kant, Fichte and Schelling. ${ }^{20}$ What has been shown is that, under the influence of concerns about Kant's philosophy, the post-Kantians close the gap between creation and discovery. The notion of creative-discovery, then, was common currency within philosophy, as well as literary circles, during the period within which romanticism flourished. ${ }^{21}$ 
This, I hope, goes some way towards showing how what might seem a strange position was in fact an intelligible perspective to adopt.

Of course, it is not obvious that creativity was accessing the 'right sort' of truths in the hands of the romantics. Schelling had defended the claim that creativity could grant epistemic access to the Absolute; Fichte had suggested that we come to know of the self and world by an act of creative-discovery. The post-Kantians, then, focused on the possibility of acquiring foundational philosophic knowledge via the creative or aesthetic act. These were not the sorts of truths that Coleridge, Wordsworth, and the other British romantics, had in mind for creativediscovery. Rather, they set their sights on far broader truths: truths about the meaningful goals of life and art, about the emotions, and about social arrangements.

This was no arbitrary choice. The post-Kantians had put creativity to work in finding philosophic foundations as a solution to the problem of philosophic scepticism. Philosophic scepticism was not the primary concern of the romantics, however, and in appealing to imagination, they sought to protect not philosophy, but rather values and ideals from being undermined by the discursive reason ('Understanding', in Coleridge's terminology.) The British romantics sought to answer the concern that on its own, this mode of reason could not act as a foundation for our ethical lives (where 'ethical' is taken to be broader than 'moral', pertaining also to our aesthetic, religious, and social practices). This was a worry generated by a view of the discursive reason as essentially negative - as without limit in its ability to dissect arguments, identify fallacies, and analyse claims, but unable by itself to put anything in place of the value-sustaining beliefs it undermined. $^{22}$ The imagination was to play this central generative role, establishing truths that were beyond the range of free critique.

This is of course not to say that the values and ideals that the authors sought to place on the foundation of the imagination were unified. Coleridge in the Biographia Literaria set out the epistemological grounds that would be used in Church and State to shore up social truths against the encroachment of instrumental reason, and to ensure continuity and reform of specific institutions. A similar romantic cognitivist technique is put to quite different use by Wordsworth in the Prelude, where the aim is the consolidation of truths of a more personal kind. The goal here is to document the growth of the mind of the poet and the overcoming of disenchantment: a growth of imagination accompanied by a renovation of ideals. Blake utilises the imagination in order to establish truth that is ultimately religious and mythological-guarding against an undermining critique of Christianity and reconstructing a more motivationally effective faith.

In this sense, the British romantics were far more ambitious about the cognitive results of creativity than the post-Kantians. While it may well be that these broader ethical claims can be justified by an appeal to intellectual intuition, it is not obvious that the romantics ever seriously attempted this derivation. If, as Schelling thought, an act of creativity grants access to the Absolute, which can be taken to transcend the distinction between particular truths and to encompass all truth, the development of ideals and values might in itself be taken to be relatively straightforward. If genuinely unimpeded creative acts grant access to all truth, they thereby grant access to truths of art, life, and politics; knowledge of the Absolute would imply the knowledge of our ethical lives that Coleridge, Wordsworth, Blake, and others sought. But, of course, lest the position be taken to authorise any and all beliefs dreamt up, it remains imperative that genuine and unconstrained creative acts can be distinguished from acts that only appear so to their possessors and others. There must, that is to say, be criteria to enable one to identify instances and non-instances of genuine creativity — and that is something that the romantics never offered. 
Knowledge about how we ought to live was perhaps not what the post-Kantians had in mind when suggesting that creativity can access truth. Nevertheless, the British romantics' claim has had enduring influence, even if it now seems strange when spelt out explicitly, as has been done here. This is surely because there is something appealing in the claim that we are the authors of our own values and ideals, which nevertheless remain more than simple fantasies. It was only in the philosophic climate that post-Kantianism had initiated that this broader romantic cognitivist position could have been so successfully articulated.

\section{Notes}

${ }^{1}$ The term 'romantic cognitivism' is my own, and I use it hesitantly, not wishing to imply any relation to the recent movement of cognitive literary studies. (I thank an anonymous reviewer for drawing my attention to this risk.) As we shall see, the romantics think that acts of creativity can grant knowledge-they can be as such acts of cognition, directed towards the apprehension of truth, and it is this connection that I mean the term 'romantic cognitivism' to capture. The position could be contrasted to the claim that acts of creativity are at base only expressive, and as such do not result in cognitive achievement. See, for example, Gibson, who employs a similar usage.

${ }^{2}$ On the historical transmission of these Kantian and post-Kantian ideas into England, see Ashton The German Idea, Hamilton Coleridge and German philosophy, Micheli "The Early Reception of Kant's Thought in England 1785-1805”, and Wellek Immanuel Kant in England, 1793-1838.

${ }^{3}$ In this essay, I will focus primarily on the Romantic use of post-Kantian ideas that had their origin in Kant's theoretical philosophy. As such, I will not engage directly with Kant's aesthetics. See Brodsky for a treatment of the relation of imagination and truth specifically in the aesthetics of Kant.

${ }^{4}$ See Berkley (187-210) for discussion of the distinction and contextually informed interpretation.

${ }^{5}$ Such is Wordsworth's description of his state of mind at Cambridge, when his mental life was passive, characterised by "Read[ing] lazily in lazy books" (Prelude 41; bk. 3: 254). He is, however, ambiguous about the state of his imagination even in this stage of his life: "Imagination Slept / And yet not utterly" (Prelude 41; bk. 3: 260-1). We should note, however, to the extent that imagination is genuinely engaged by reading poetry at this stage, it is again linked to truth. "Yea, our blind Poet, who in his later day, / Stood almost single, uttering odious truth" (Prelude 42; bk. 3: 284-5).

${ }^{6}$ Blake writes, for instance, "The Eternal Body of Man is The Imagination, that is, God himself, The Divine Body, Jesus" (Laocoön Plate qtd. in Damon 195). Yet, however strange this doctrine becomes it is clear that Blake retains a belief in the instrumental truth-tracking value of imagination and, as Robert Ryan notes, he "always sees the imagination as the conduit of religious truth" (163). (2).

${ }^{7}$ See Stillinger for an account of how "Keats came to learn that the kind of imagination he pursued was a false lure"

${ }^{8}$ We should note that Keats does not draw Coleridge's distinction between Fancy and Imagination: for him, the two are identical.

${ }^{9}$ See J. Wordsworth: "Aside from Byron, all the Romantic poets attempted serious, complex definitions of imagination." (486)

${ }^{10}$ Of those who occupy fringe territory in the traditional romantic canon, it is most obviously Carlyle, steeped in German philosophy, who continues in this line. Quoting from Goethe, he describes "Truth, eternal Reason, / Which from Beauty takes its dress" as "the end of Poetry at all times" ("State of German Literature" 70-1). He writes that the poet is " $[\mathrm{a}] \mathrm{n}$ inspired Soul once more vouchsafed us, direct from Nature's own great fire-heart, to see the Truth, and speak it, and do it" (Past and Present 107). When Carlyle discusses the Poet as Hero, the cognitive role is returned to once again. The Poet has "penetrated ... into the sacred mystery of the Universe" (Heroes and Hero Worship 95).

${ }^{11}$ I thank an anonymous reviewer for pressing me on this point.

${ }^{12}$ When referring to Kant, I quote from The Cambridge Edition of the Works of Immanuel Kant with Academy Edition references. I follow convention in using the following abbreviations: Critique of Pure Reason (CPR), Critique of Practical Reason (CPrR), Critique of Judgment (CJ), Lectures on Metaphysics (LM).

${ }^{13}$ For brevity, in what follows, I confine my discussion to the aspects of 'intellectual intuition' that do not involve Kant's claim that a being possessed of intellectual intuition would be a being capable of perceiving things-in-themselves, and the whole of nature as a unity. Gram suggests that these are better seen as different doctrines, to which Kant merely gives the same name. ("Kant uses one designation to cover three very different issues" which are "logically independent" 
(288)). I do not wish to take a stance on this issue, but will concentrate on what Gram identifies as the second sense of the term - "the conception of an intellect that would create its own objects just in knowing them" (292). This sense, along with the third, seems the most important aspect to understanding romanticism. I do not address Gram's claim that the use of intellectual intuition in Kant is significantly divergent from that in Fichte and Schelling: for the purposes here, I assume showing the existence of a general intellectual thread will suffice. Gram's claim, however, has not gone undisputed. See Estes (165-174).

${ }^{14}$ See, for instance, LM 29: 800: “if a being had intellectual intuition, as we think of God”. See also LM 29: 954.

${ }^{15}$ See also Pippin (Idealism as Modernism) for a useful discussion of the connection to the spontaneity of the divine intellect: "when God's intuition is said to be 'spontaneous', Kant means that it 'creates' (a sufficient but not necessary condition of spontaneity) the instances or objects it intuits" (31).

${ }^{16}$ In what follows, I refer to Fichte's Wissenschaftslehre by way of W followed by academy reference, using Heath and Leach's translation in The Science of Knowledge.

${ }^{17}$ We should note that Fichte claims not to be using the term 'intellectual intuition' in Kant's sense, highlighting passages in which Kant speaks of intellectual intuition granting access to noumena, an entity that Fichte denies the existence of. See W 1.172. This seems to be an issue of intellectual loyalty to the founder of the critical philosophy, however: in the other aspects, Kant and Fichte's conceptions of intellectual intuition share much. See Beiser (299-301).

${ }^{18}$ It cannot be reasonably doubted that positing is a creative act. Besides committing to the spontaneity of such positing, Fichte often utilises the vocabulary of creativity. See, for instance: W 1.174, 1.427, 1.429.

${ }^{19}$ References to the Schelling's System of Transcendental Idealism will be signalled in text by STI followed by page reference to this edition; references to references to the Idea for a Philosophy of Nature will be signalled in text by IPN followed by page reference to this edition. In both cases, I make use of Heath's translation.

${ }^{20}$ See n.1.

${ }^{21}$ See Stone for a discussion of how the themes tackled in this paper were extended by Novalis and Schlegel.

${ }^{22}$ Under the influence of Coleridge, John Stuart Mill captures the British romantic concern with the discursive reason well. Writing about Bentham, Hume, and the philosophes, he writes: " $\mathrm{t}$ ]o tear away, was indeed all that these philosophers, for the most part, aimed at: they had no conception that anything else was needful” (131-2). They saw "what was not true, not what was" (139).

\section{References}

Abrams, Meyer H. The Mirror and the Lamp. New York, NY: W.W. Norton, 1958. Print. - Natural Supernaturalism. New York, NY: W.W. Norton, 1973. Print.

Ashton, Rosemary. The German Idea: Four English Writers and the Reception of German Thought 1800-1860 Cambridge: Cambridge UP, 1980. Print.

Beiser, Frederick C. German Idealism: the Struggle Against Subjectivism 1781-1801 (Cambridge, MA: Harvard UP, 2002). Print.

Berkley, Richard. Coleridge and the Crisis of Reason. Oxford: Oxford UP, 2007. Print.

Blake, William. The Complete Poetry and Prose of William Blake. Ed. D.V. Erdman. Berkley, CA: University of California Press, 2008. Print.

Bowie, Andrew. Schelling and Modern Philosophy. London: Routledge, 1993. Print.

Bowra, Cecil M. The Romantic Imagination. London: Oxford UP, 1950. Print.

Brodsky, Claudia. “'Judgment' and the Genesis of What We Lack: 'Schema,' 'Poetry,' and the 'Monogram of the Imagination' in Kant." The Eighteenth Century 51.3 (2010): 317-340. Project Muse. Web.

Carlyle, Thomas. Heroes and Hero Worship (London: Chapman Hall, 1869). Print. Past and Present. London: Chapman and Hall, 1870. Print.

. "State of German Literature." Critical and Miscellaneous Essays. Vol. 1. New York: John B. Alden, 1885. Print.

Coleridge, Samuel Taylor. Collected Works of Samuel Taylor Coleridge. Princeton, NJ: Princeton UP and London: Routledge and Kegan Paul, 1969-. Print. 
Damon, S. Foster. A Blake Dictionary: Ideas and Symbols of William Blake. London: Thames and Hudson, 1973. Print.

Dickerson, Adam B. Kant on Representation and Objectivity. Cambridge: Cambridge UP, 2003. Print.

Estes, Yolanda. "Intellectual Intuition: Reconsidering Continuity in Kant, Fichte, and Schelling." Fichte, German Idealism, and Early Romanticism Fichte-Studien-Supplementa 24. Ed. Daniel Breazeale and Tom Rockmore. New York, NY: Rodopi, 2010. 165-179. Print.

Fichte, Johann Gottlieb. The Science of Knowledge. Trans. and ed. P. Heath J. Leach. Cambridge: Cambridge UP, 1982. Print.

Freydberg, Bernard. Imagination in Kant's Critique of Practical Reason. Bloomington, IN: Indiana UP, 2005. Print.

Frye, Northrop. Fearful Symmetry: A Study of William Blake. Princeton, NJ: Princeton UP, 1969

Gardner, Sebastian. Kant and the Critique of Pure Reason. London: Routledge, 1999. Print.

Gibson, John. "Cognitivism in the Arts." Philosophy Compass 3/4 (2008): 573-589. Wiley Online Library. Web. 9 Nov. 2013.

Gram, Moltke S. "Intellectual Intuition: The Continuity Thesis." Journal of the History of Ideas 42.2 (1981): 287-304. Print.

Hamilton, Paul. Coleridge and German Philosophy: the Poet in the Land of Logic. London: Continuum, 2007. Print.

Hanna, Robert. Kant and the Foundations of Analytic Philosophy. Oxford: Oxford UP, 2001. Print.

Höffe, Otfried. Kant's Critique of Pure Reason: The Foundation of Modern Philosophy. London: Springer, 2010. Print.

Horstmann, Rolf-Peter. "The Early Philosophy of Fichte and Schelling." The Cambridge Companion to German Idealism. Ed. Karl Ameriks. Cambridge: Cambridge University Press, 2000. 127-35. Print.

Hume, David. A Treatise of Human Nature. Ed. David F. Norton and Mary J. Norton. Oxford: Oxford UP, 2000. Print.

Kant, Immanuel. The Cambridge Edition of the Works of Immanuel Kant. Ed. Paul Guyer and Allen Wood. Cambridge: Cambridge UP, 1995-. Print.

Keats, John. The Major Works. Ed. Elizabeth Cook. Oxford: Oxford UP, 1990. Print.

Larmore, Charles E. The Romantic Legacy. New York, NY: Columbia UP, 1996. Print.

Maimon, Salomon. Essay on Transcendental Philosophy. Trans. Alistair Welchman, Henry Somers-Hall, Merten Reglitz, and Nick Midgley. London: Continuum, 2010. Print.

Micheli, Giuseppe. "The Early Reception of Kant's Thought in England 1785-1805." Kant and his Influence. Ed. George M. Ross and Tony McWalter. Bristol: Thoemmes Books, 1990. 202-314. Print.

Mill, John Stuart. "Coleridge." Collected Works ofJohn Stuart Mill. Vol. 10. Ed. John M. Robson. London: Routledge Kegan Paul, 1963-1991. Print.

Perkins, Mary A.. "Coleridge." The Routledge Encyclopaedia of Philosophy. Vol. 2. Ed. Edward Craig. London: Routledge, 1998. 403-406. Print.

Pinkard, Terry. German Philosophy 1760-1860. Cambridge: Cambridge UP, 2002. Print.

Pippin, Robert. Hegel's Idealism: the Satisfactions of Self-Consciousness. Cambridge: Cambridge UP, 1989. Print.

Idealism as Modernism. Cambridge: Cambridge UP, 1997. Print.

Ryan, Robert. "Blake and Religion." Cambridge Companion to Blake. Ed. Morris Eaves. Cam- 
bridge: Cambridge UP, 2003. 150-168. Print.

Schelling, Friedrich Wilhelm Joseph. Ideas for a Philosophy of Nature. Trans. P. Heath. Cambridge: Cambridge UP, 1988. Print.

- System of Transcendental Idealism (1800). Trans. P. Heath. Charlottesville, VA: University of Virginia, 1978. Print.

Shelley, Percy Bysshe. A Defence of Poetry. Vol. 7 of The Complete Works of Percy Bysshe Shelley. Ed. Roger Ingpen and Walter E. Peck. London: Ernest Benn Limited, 1965. Print.

Siep, Ludwig. "Fichte." A Companion to Continental Philosophy. Ed. Simon Critchley and William R. Schroeder. Oxford: Blackwell Publishing Ltd, 1998. 57-67. Print.

Solomon, Robert C. Continental Philosophy Since 1750: the Rise and Fall of the Self. Oxford: Oxford UP, 1988. Print.

Stone, Allison. "The Romantic Absolute." British Journal for the History of Philosophy 19.3 (2011): 497-517. Print.

Stillinger, Jack. "Imagination and Reality in the Odes of Keats." Twentieth Century Interpretations of Keats's Odes: A Collection of Critical Essays. Ed. Jack Stillinger. Englewood Cliffs, N.J.: Prentice-Hall, 1968. 1-16. Print.

Wellek, Rene. Immanuel Kant in England, 1793-1838. Princeton, NJ: Princeton UP, 1931. Print.

Wordsworth, Jonathan. “The Romantic Imagination.” A Companion to Romanticism. Ed. Duncan Wu. Oxford: Blackwell, 1999. 486-494. Print.

Wordsworth, William. Lyrical Ballads. London: Routledge, 1991. Print.

. The Prelude: or Growth of a Poet's Mind (Text of 1805). Ed. Ernest De Selincourt and Stephen Gill. Oxford: Oxford UP, 1970. Print. 